\title{
Technology And The Seven Principles
}

\author{
Joyce Nki, (E-mail: nkij@cookman.edu), Bethune-Cookman College
}

\begin{abstract}
This paper reports the lessons learned and outcomes of effective implementation of the Seven Principles for Good Practice in Teaching and learning, using technology in the traditional classroom. Teaching Old Testament to undergraduate students challenges the instructor to look for alternative instructional techniques. Use of technology has created an environment where teaching has been productive, fun, and fulfilling, while learning has been participatory, collaborative, interactive, beneficial, and critically effective. The course has been divided into modules that carry a specific topic. The appropriate use of seven principles in these modules has enhanced the understanding of the basic concepts for learners because each module carries on and advances the concept that was taught in the previous module.
\end{abstract}

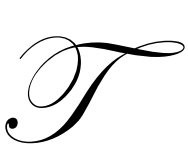

his paper will discuss how technology was used to implement innovative teaching and learning environments as stipulated by the Seven Principles for Good Practice in Teaching and learning. The paper reports the lessons learned and outcomes of effective implementation of the seven principles using technology in a traditional face-to-face class offered in the fall 2004. The purpose of using technology was to provide students with opportunities to increase comprehension of concepts presented in the Old Testament introductory course.

Since the inception of the Seven Principles for Good Practice in Undergraduate Education in 1987, they have become useful tools in improving Teaching and Learning in Colleges and Universities. The unique thing about The Seven Principles is how easily they adapt to the use of technology to either enhance the traditional classroom teaching or online teaching.

Since the word "Technology" is so broad, I will briefly share with you the technology tools or components that powerfully transformed the Learning and Teaching of the Old Testament introductory course. It is a success story of how simple tools empowered the Seven Principles and transformed the Learning and Teaching of the Old Testament Introductory course to the undergraduate students.

Here below you will see a short description of the Principle and the technology tools that were used to enhance the Seven Principles:

\section{PRINCIPLE 1 \& TECHNOLOGY}

\section{Good Practice Encourages Contact Between Students and Faculty}

"Frequent student-faculty contact in and outside of class is a most important factor in student motivation and involvement....Knowing a few faculty members well enhances students' intellectual commitment and encourages them to think about their own values and plans."

The Technology I used for this principle was email and Microsoft editor. In the beginning of the semester I required students to have their college email accounts activated. The emails enabled me to get in touch with them at a personal level and respond to each student's need in a private and secure way. Some were free to share with me their backgrounds and life situations, which they otherwise could not have shared in a classroom setting. I was able to share my personal life experiences with those I felt they needed encouragement to put more effort on their studies 
and pursue their education. To some others, I shared my life experience to encourage them not to give up on life but to try and pursue their dreams.

I also required term papers to be submitted as attachments to emails. Using Microsoft editor made it easier and convenient for me to grade their epapers and respond to students more intimately as a counselor and role model. If students did not agree with my comments, it was easy for them to write back and question my comments. And since I was left with a copy of their paper I responded back with an explanation.

\section{PRINCIPLE 2 \& TECHNOLOGY}

\section{Good Practice Encourages Cooperation Among Students}

"Working with others often increases involvement in learning. Sharing one's ideas and responding to others' improves thinking and deepens understanding."

Using this guideline, I divided the class into four teams. Each team's name was an Old Testament biblical character. The purpose was to help students to identify themselves with the biblical characters they will meet in their study of the Old Testament and be able to comprehend the main concepts and themes as they worked together on group discussion topics given in each module.

The students had to use Microsoft Word editor as well as electronic mail to communicate with each other. The first person on the team list (team chief) was to respond to the topic and email his/her response to other team members as an attachment. The other members of the team were to use the Microsoft word editor and indicate the following and send back the draft to the team chief:

a. Areas where they thought their team member had accurately interpreted the readings, or even clarified some particular point for them.

b. $\quad$ Areas where they felt their team member had missed the boat and failed to understand the material.

c. Suggestions for further study of the topic, or some practical application of the material under question.

After the team members have agreed on the correct responses to discussion topic, then the "team chief" will compiled the team report and sent it to me as an attachment to an email by the due date.

Technology provided communication tools that opened an arena where collaborative learning improved students' thinking and understanding.

\section{PRINCIPLE 3 \& TECHNOLOGY}

\section{Good Practice Encourages Active Learning Techniques}

"Students must talk about what they are learning, write reflectively about it, relate it to past experiences, apply it to their daily lives, and they must make what they learn part of themselves."

Moving from the group learning experience, I concentrated on individual student learning. After they mastered the main concepts, I asked each student to write two personal reflective papers, one just before the mid of the semester and the other a week before the final exams. In these papers I asked them to respond to the following:
a) state the major
b) why they chose that major
c) how the Old Testament course relates to other courses they were taking that semester
d) how this course relates to their major and
e) how this course relates to their career goals. 
The papers were to be submitted as an attachment to an email to me. I graded their papers using Microsoft editor and returned them back to students through the same process. In addition to reflective epapers, I gave them web based self-practice quizzes.

\section{PRINCIPLE 4 \& TECHNOLOGY}

\section{Good Practice Gives Prompt Feedback}

"Students need frequent opportunities to perform and receive feedback on their performance, chances to reflect on what they have learned, what they still need to know, and how they might assess themselves".

Teaching Introduction courses to over 150 students a semester can be tiring, frustrating, time consuming, and lack of commitment to give timely feedback to students. This can lead to frustration and discouragement to both teacher and student. Technology however enhances this principle. In my case, email became an excellent tool in responding promptly to student's personal issues or questions regarding missed class assignments and due dates as well as looking for my students when they missed class. In addition to email, I used Micrograde, software that computerizes grade and gives instance students' grade average. This made it easier for me to give students report on their grade average very time they turn in an assignment.

Half of my quizzes was given through the World Wide Web that were computer-graded in real time, offering rapid and timely feedback to students. The other half of the quizzes was done in class, and students used scantron forms, which takes a few seconds to grade. The prompt feedback enhanced by these tools helped most students to spot the areas of their weaknesses which needed improvement. Prompt feedback was useful to instruction as well since I was able to know the areas I needed to pay more attention when reviewing for midterm and final exam.

\section{PRINCIPLE 5 \& TECHNOLOGY}

\section{Good Practice Emphasizes Time on Task}

"Allocating realistic amounts of time means effective learning for students and effective teaching for faculty."

All due dates for quizzes, exams, papers, and class presentations were all put on the syllabus. However, a week before each due date I sent out emails reminding students the upcoming assignment and the requirements for that work. Through the email, I reached students at a personal level showing them that I care. This personal touch made them feel responsible and accountable. Most of the assignments were required to be submitted through the World Wide Web or as attachment to an email and submitted before 11:55 PM, giving them reasonable time to work on their assignments.

\section{PRINCIPLE 6 \& TECHNOLOGY}

\section{Good Practice Communicates High Expectations}

"Expecting students to perform well becomes a self-fulfilling prophecy when teachers and institutions hold high expectations for themselves and make extra efforts."

This principle ties well with Principle I and II. However, this is the one Principle that required a higher commitment on my side as a teacher. I made sure I graded all the 300 self reflective epapers using Microsoft editor and returned to students on timely bases. I wrote /responded to more than 800 emails. As I graded these papers I could see where each student was and responded to them personally. Since I knew that my comments will get back to them privately, I did let each one of them know what I expected of them and that they are capable of passing the class with better than what they had then. Technology enabled me to serve as a mentor and informal advisor to students individually. 


\section{PRINCIPLE 7 \& TECHNOLOGY}

\section{Good Practice Respects Diverse Talents and Ways of Learning}

"Students need opportunities to show their talents and learn in ways that work for them. Then they can be pushed to learn in new ways that do not come so easily."

I acknowledge that people learn differently and each individual is entitled to his/her learning style. Technology enhances this principle in a variety of ways. In my Old Testament class I asked students to watch video-tapes and news related to biblical world, to search the internet for audio Bible and listen to someone reading the text we were dealing with in class that time.

I gave web-based practice quizzes and asked students to read the Bible out loud in class. Such technology provided students with different means of interaction with the biblical text and learn through . extra materials that enabled students not only rely on my lecture notes and discussion groups but other alternatives that provided other means of learning.

\section{Learning Outcomes}

The following are the benefits and challenges of the use of technology in a traditional classroom:
a. Collaborative learning
b. Conflict resolved smoothly
c. Greater participation in class
d. Concepts easily understood
e. Students able to relate the concepts to their major
f. Application of knowledge to real life and career goals
g. $\quad$ Cost effective (less paper \& ink
h. Better management of instructional time and office hours

However, there were undeniable challenges:
a. Many hours of preparations
b. Many hours on the computer
c. Failure of server once in a while
d. Students who felt uncomfortable with computers

\section{REFERENCES}

1. Chickering, Arthur W. and Gamson, Zelda F. Seven Principles for Good Practice in Undergraduate Education. Retrieved February 11, 2005 from World Wide Web http://www.hcc.hawaii.edu/intranet/ committees/ FacDevCom/guidebk/teachtip/7princip.htm.

2. Chickering, Arthur W. and Gamson, Zelda F. Fall 2004. 7 principles with suggestions. Retrieved February 11, 2005 from World Wide Web http://web.grcc.cc.mi.us/ctl/7princip.htm.

3. Winona State site- 7 principles with examples of how they are implemented. Retrieved February 11, 2005 from the World Wide Web http://www.winona.msus.edu/president/seven.htm.

4. Chickering, Arthur W. and Gamson, Zelda F. Applying the Seven Principles for Good Practice in Undergraduate Education. Retrieved February 11, 2005 from the World Wide Web http://www.msu.edu/user/ coddejos/seven.htm.

5. Indiana University, Bloomington. Online Library: Principles of Good Practice in Undergraduate Education. Retrieved February 11, 2005 from the World Wide Web http://www.indiana.edu/ icy/ omnteach.html\#ontime. 


\section{APPENDIX}

Seven Principles For Good Practice in Teaching and Learning

1. Good Practice Encourages Contact Between Students and Faculty: Frequent student-faculty contact in and out of classes is the most important factor in student motivation and involvement. Faculty concern helps students get through rough times and keep on working. Knowing a few faculty members well enhances students' intellectual commitment and encourages them to think about their own values and future plans.

2. Good Practice Develops Reciprocity and Cooperation Among Students: Learning is enhanced when it is more like a team effort that a solo race. Good learning, like good work, is collaborative and social, not competitive and isolated. Working with others often increases involvement in learning. Sharing one's own ideas and responding to others' reactions sharpens thinking and deepens understanding.

3. Good Practice Encourages Active Learning: Learning is not a spectator sport. Students do not learn much just by sitting in classes listening to teachers, memorizing pre-packaged assignments, and spitting out answers. They must talk about what they are learning, write about it, relate it to past experiences and apply it to their daily lives. They must make what they learn part of themselves.

4. Good Practice Gives Prompt Feedback: Knowing what you know and don't know focuses learning. Students need appropriate feedback on performance to benefit from courses. When getting started, students need help in assessing existing knowledge and competence. In classes, students need frequent opportunities to perform and receive suggestions for improvement. At various points during college, and at the end, students need chances to reflect on what they have learned, what they still need to know, and how to assess themselves.

5. Good Practice Emphasizes Time on Task: Time plus energy equals learning. There is no substitute for time on task. Learning to use one's time well is critical for students and professionals alike. Students need help in learning effective time management. Allocating realistic amounts of time means effective learning for students and effective teaching for faculty. How an institution defines time expectations for students, faculty, administrators, and other professional staff can establish the basis of high performance for all.

6. Good Practice Communicates High Expectations: Expect more and you will get more. High expectations are important for everyone -- for the poorly prepared, for those unwilling to exert themselves, and for the bright and well motivated. Expecting students to perform well becomes a selffulfilling prophecy when teachers and institutions hold high expectations for themselves and make extra efforts.

7. Good Practice Respects Diverse Talents and Ways of Learning: There are many roads to learning. People bring different talents and styles of learning to college. Brilliant students in the seminar room may be all thumbs in the lab or art studio. Students rich in hands-on experience may not do so well with theory. Students need the opportunity to show their talents and learn in ways that work for them. Then they can be pushed to learn in new ways that do not come so easily.

Adapted from the booklet, "Seven Principles for Good Practice in Undergraduate Education," created by Zelda Gamson and Arthur W. Chickering, available from The Johnson Foundation, Inc., Processing Center, P.O. Box 17305, Milwaukee, WI 53217. 


\section{NOTES}

